\title{
Whole-cell biocatalysis for hydrogen storage and syngas conversion to formate using a thermophilic acetogen
}

\author{
Fabian M. Schwarz and Volker Müller ${ }^{*}$ []
}

\begin{abstract}
Background: In times of global climate change, the conversion and capturing of inorganic $\mathrm{CO}_{2}$ have gained increased attention because of its great potential as sustainable feedstock in the production of biofuels and biochemicals. $\mathrm{CO}_{2}$ is not only the substrate for the production of value-added chemicals in $\mathrm{CO}_{2}$-based bioprocesses, it can also be directly hydrated to formic acid, a so-called liquid organic hydrogen carrier (LOHC), by chemical and biological catalysts. Recently, a new group of enzymes were discovered in the two acetogenic bacteria Acetobacterium woodii and Thermoanaerobacter kivui which catalyze the direct hydrogenation of $\mathrm{CO}_{2}$ to formic acid with exceptional high rates, the hydrogen-dependent $\mathrm{CO}_{2}$ reductases (HDCRs). Since these enzymes are promising biocatalysts for the capturing of $\mathrm{CO}_{2}$ and the storage of molecular hydrogen in form of formic acid, we designed a whole-cell approach for $T$. kivui to take advantage of using whole cells from a thermophilic organism as $\mathrm{H}_{2} / \mathrm{CO}_{2}$ storage platform. Additionally, $T$. kivui cells were used as microbial cell factories for the production of formic acid from syngas.

Results: This study demonstrates the efficient whole-cell biocatalysis for the conversion of $\mathrm{H}_{2}+\mathrm{CO}_{2}$ to formic acid in the presence of bicarbonate by T. kivui. Interestingly, the addition of $\mathrm{KHCO}_{3}$ not only stimulated formate formation dramatically but it also completely abolished unwanted side product formation (acetate) under these conditions and bicarbonate was shown to inhibit the membrane-bound ATP synthase. Cell suspensions reached specific formate production rates of $234 \mathrm{mmol}_{\text {protein }}^{-1} \mathrm{~h}^{-1}\left(152 \mathrm{mmol} \mathrm{g}_{\mathrm{CDW}}^{-1} \mathrm{~h}^{-1}\right)$, the highest rates ever reported in closed-batch conditions. The volumetric formate production rate was $270 \mathrm{mmol} \mathrm{L}^{-1} \mathrm{~h}^{-1}$ at $4 \mathrm{mg} \mathrm{mL}^{-1}$. Additionally, this study is the first demonstration that syngas can be converted exclusively to formate using an acetogenic bacterium and high titers up to $130 \mathrm{mM}$ of formate were reached.
\end{abstract}

Conclusions: The thermophilic acetogenic bacterium T. kivui is an efficient biocatalyst which makes this organism a promising candidate for future biotechnological applications in hydrogen storage, $\mathrm{CO}_{2}$ capturing and syngas conversion to formate.

Keywords: Carbon capture, Syngas, Whole-cell biocatalysis, Closed-batch fermentation, Hydrogen-dependent $\mathrm{CO}_{2}$ reductase, Formate dehydrogenase, Hydrogenase, Thermophiles, Thermoanaerobacter kivui

*Correspondence: vmueller@bio.uni-frankfurt.de

Molecular Microbiology \& Bioenergetics, Institute of Molecular Biosciences, Johann Wolfgang Goethe University, Max-von-Laue-Str. 9, 60438 Frankfurt am Main, Germany

\section{Background}

Carbon dioxide and syngas are considered as "renewable options" in biotechnological applications, especially in times of global climate change and gradual increase of atmospheric $\mathrm{CO}_{2}[1,2]$. Among the organisms able to reduce $\mathrm{CO}_{2}$, strictly anaerobic, acetogenic bacteria have gained much attraction in recent years [3-5] because 
they can use $\mathrm{H}_{2}$ and $\mathrm{CO}$ as reductant for $\mathrm{CO}_{2}$ reduction. The use of acetogenic bacteria to produce ethanol from syngas $\left(\mathrm{H}_{2}, \mathrm{CO}, \mathrm{CO}_{2}\right)$ is already realized on an industrial scale $[6,7]$. The first step in acetogenic $\mathrm{CO}_{2}$ reduction is the reduction of $\mathrm{CO}_{2}$ to formic acid (Fig. 1). Acetogens are phylogenetically very diverse and employ different enzymes for this reaction [8, 9]. Typically, they have NADP- or ferredoxin-dependent formate dehydrogenases [10-12], whereas Acetobacterium woodii and Thermoanaerobacter kivui have a different enzyme, a hydrogen-dependent $\mathrm{CO}_{2}$ reductase (HDCR) [13, 14]. This enzyme has a formate dehydrogenase module and a [FeFe]-hydrogenase module that are connected by two small FeS-containing proteins. In contrast to formate dehydrogenases, these enzymes can use molecular hydrogen directly as reductant for $\mathrm{CO}_{2}$, without the need for external soluble cofactors. Interestingly, the enzyme also accepts electrons from CO (via ferredoxin) [14], making it a catalyst for the conversion of syngas to formic acid. The HDCR not only reduces $\mathrm{CO}_{2}$ with remarkable catalytic activities but also oxidizes $\mathrm{H}_{2}$ and, thus, can be used to kill two birds with one stone $[14,15]$. Apart from $\mathrm{CO}_{2}$ reduction, it can be used to store hydrogen gas in

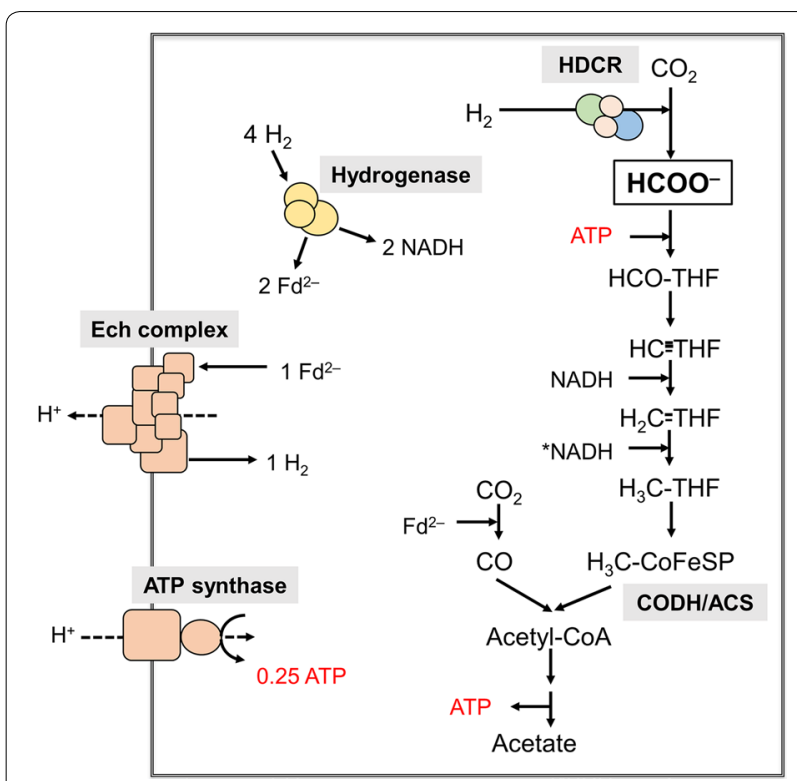

Fig. 1 Model of the biochemistry and bioenergetics of acetogenesis from $\mathrm{H}_{2}+\mathrm{CO}_{2}$ in T. kivui. The bioenergetics and biochemistry of acetogenesis from $\mathrm{H}_{2}+\mathrm{CO}_{2}$ by T. kivui are shown. CODH/ACS, $\mathrm{CO}$ dehydrogenase/acetyl-CoA synthase; Ech, energy-conserving hydrogenase; $\mathrm{HDCR}$, hydrogen-dependent $\mathrm{CO}_{2}$ reductase; hydrogenase, electron bifurcation hydrogenase; $\mathrm{THF}$, tetrahydrofolic acid; HCO-THF, formyl-THF; HC-THF, methenyl-THF; $H_{2} C-T H F$, methylene-THF; $\mathrm{H}_{3} \mathrm{C}-\mathrm{THF}$, methyl-THF; CoFeSP, corrinoid iron-sulfur protein; $\mathrm{Fd}^{2-}$, reduced ferredoxin; ${ }^{*}$ reduction of methylene-THF might occur using an electron donor with a similar redox potential as $\mathrm{NADH}$ a liquid, non-toxic product, formic acid or its base, formate, a so-called liquid organic hydrogen carrier (LOHC) $[16,17]$. The equilibrium constant for the conversion of $\mathrm{CO}_{2}+\mathrm{H}_{2}$ to formic acid is close to one and, therefore, it is an ideal biocatalyst for the storage of $\mathrm{H}_{2}$. All other enzymes known, including the membrane-bound formate hydrogen lyase of Escherichia coli have a strong bias towards formate oxidation and reduce $\mathrm{CO}_{2}$ only under harsh conditions with low activities $[18,19]$.

The isolated HDCR from $A$. woodii and T. kivui require strictly anoxic conditions which makes an application rather difficult. Using $A$. woodii, we have overcome this problem by establishing an efficient whole-cell system to convert $\mathrm{H}_{2}+\mathrm{CO}_{2}$ to formic acid and vice versa $[14,15]$. This system makes use of the ATP-dependent further conversion of formate in acetogens (Fig. 1). By lowering the cellular ATP content, formate is no longer reduced to acetate and stoichiometrically produced from $\mathrm{H}_{2}+\mathrm{CO}_{2}$. However, A. woodii cannot grow on syngas or $\mathrm{CO}[20$, $21]$ and resting cells produced only little formate from syngas and high amounts of acetate were still produced as unwanted side product [14]. In contrast, the HDCR containing thermophile $T$. kivui can grow in mineral medium on $\mathrm{CO}$ or syngas [22, 23]. Therefore, we started out to analyze hydrogenation of $\mathrm{CO}_{2}$ in a whole-cell system of T. kivui with the aim to increase productivity (due to its thermophilic nature) and to establish an efficient whole-cell biocatalyst for hydrogen storage and formate production from syngas.

\section{Results}

\section{Formate production by $T$. kivui cells}

To analyze the potential use of whole cells of T. kivui as microbial cell factories for the efficient conversion of $\mathrm{H}_{2}+\mathrm{CO}_{2}$ to formate, the organism was grown in complex medium with pyruvate as substrate and resting cells were prepared. As expected, the addition of $\mathrm{H}_{2}+\mathrm{CO}_{2}$ to the cell suspension resulted in the production of acetate as the major end product with a specific acetate production rate of $19 \mathrm{mmol} \mathrm{g}_{\text {protein }}{ }^{-1} \mathrm{~h}^{-1}\left(12 \mathrm{mmol} \mathrm{g}_{\mathrm{CDW}}{ }^{-1} \mathrm{~h}^{-1}\right)$ (Fig. 2a). Formate was only produced in low amounts at the beginning of the experiment and was consumed afterwards. This is expected since formate is an intermediate in the WLP. As seen before with A. woodii, formate accumulation requires inhibition of further formate metabolism [14]. This can be achieved by reducing the energy status of the cell (Fig. 1). Hence, formate can no longer be activated due to a lack of ATP. One possibility to uncouple the energy metabolism of cells is by using ionophores. Depending on the ionophores used, there was a variation in the formate/acetate ratio after incubation with $\mathrm{H}_{2}+\mathrm{CO}_{2}$ as substrate (Fig. 2b). In contrast to $A$. woodii, whose energy metabolism is strictly $\mathrm{Na}^{+}$ 

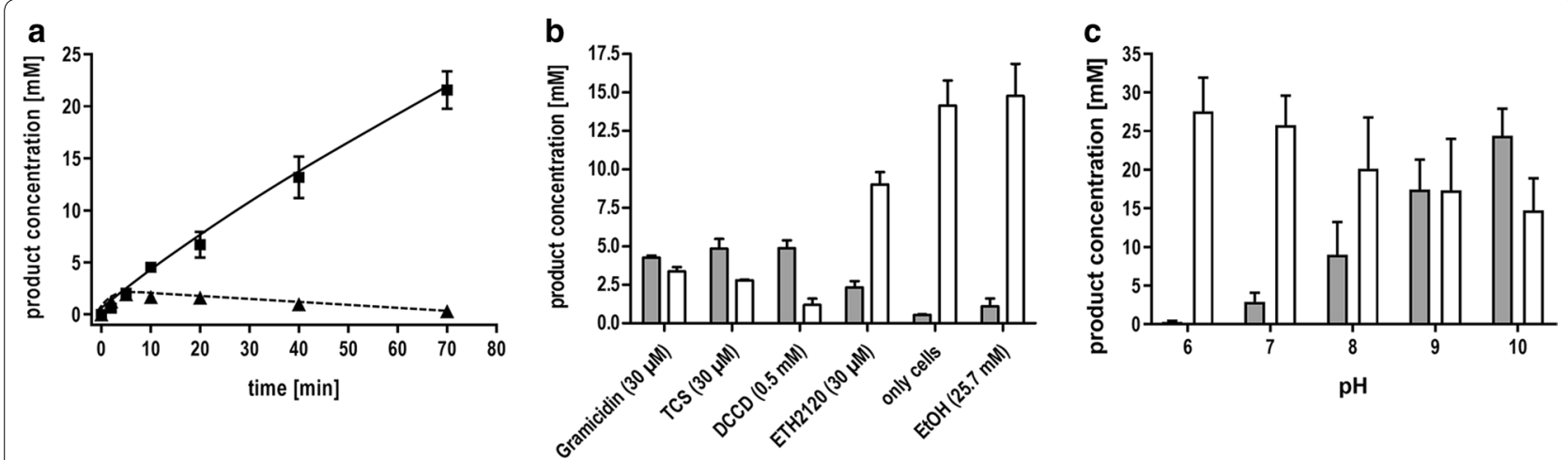

Fig. 2 Effect of ionophores/uncoupling agents and $\mathrm{pH}$ on product formation by resting cells of T. kivui. Cells were grown with $0.1 \mathrm{M}$ pyruvate,

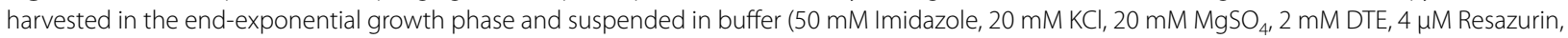
pH 7.0 or 25 mM MES, 25 mM MOPS, 25 mM HEPES, 25 mM EPPS, 25 mM CHES, 20 mM KCl, 20 mM MgSO ${ }_{4}, 2$ mM DTE, $4 \mu M$ Resazurin, pH as indicated) to a final concentration of $1 \mathrm{mg} / \mathrm{mL}$. a Cells were incubated without or $\mathbf{b}$ with ionophores/uncoupling agents or (c) at the corresponding $\mathrm{pH}$ for 10 min at $60^{\circ} \mathrm{C}$. The experiment was started by replacing the gas phase with $\mathrm{H}_{2}+\mathrm{CO}_{2}\left(80: 20 \%, 2 \times 10^{5} \mathrm{~Pa}\right)$ and the product formation was determined after 40 (b) or 90 min (c). Squares and white bars, acetic acid; triangles and grey bars, formic acid

dependent $[24,25]$, the $\mathrm{Na}^{+}$ionophore ETH2120 had almost no effect on product formation in T. kivui and the dominant compound was acetate. $9.1 \mathrm{mM}$ acetate was produced but only $2.3 \mathrm{mM}$ formate. This is consistent with previous experiments and the assumption that $\mathrm{H}^{+}$ instead of $\mathrm{Na}^{+}$is used as the coupling ion for the primary bioenergetics in T. kivui $[26,27]$. Thus, a more favorable formate to acetate ratio of 1.7 was achieved using the protonophore 3,3,4,5-tetrachlorosalicylanilide (TCS). A four times higher formate yield was detected using the ATPase inhibitor $N, N^{\prime}$-dicyclohexylcarbodiimide (DCCD). Since acetate was still produced, the membrane potential seemed to be not fully diminished by the ionophores used in this study.

Interestingly, a change in $\mathrm{pH}$ had a dramatic effect on the product yields (Fig. 2c). At pH 6.0, there was no formate produced, but formate production increased with increasing $\mathrm{pH}$. At the same time, acetate production decreased, but to a lesser extent. This led to an inversion of the formate/acetate ratio from 0.01 at $\mathrm{pH} 6.0$ to 1.7 at $\mathrm{pH} 10$.

For further experiments, we added bicarbonate to resting cells to increase the available amount of $\mathrm{CO}_{2}$ in solution and to achieve higher formate yields. At $50 \mathrm{mM}$ bicarbonate, the acetate formation rate was slightly increased by $24 \%$ and, more important, the transient formation of formate was also increased by 319\% (Fig. 3). At $300 \mathrm{mM}$ bicarbonate acetate formation was completely abolished and formate production was drastically stimulated: The formate production rate was $220 \mathrm{mmol} \mathrm{g}_{\text {protein }}^{-1} \mathrm{~h}^{-1}\left(143 \mathrm{mmol} \mathrm{g}_{\mathrm{CDW}}^{-1} \mathrm{~h}^{-1}\right)$ and the final formate concentration reached $126 \mathrm{mM}$ after $90 \mathrm{~min}$.
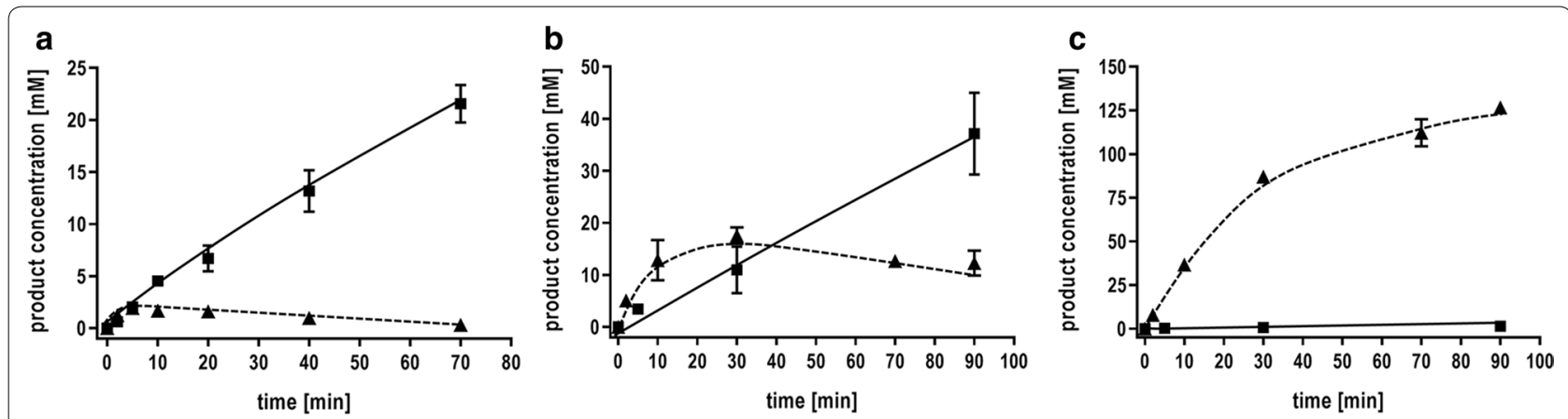

Fig. 3 Effect of bicarbonate on product formation from $\mathrm{H}_{2}+\mathrm{CO}_{2}$. a Resting cells of T. kivui ( $1 \mathrm{mg} / \mathrm{mL}$ ) were incubated in anoxic buffer ( $50 \mathrm{mM}$ Imidazole, $20 \mathrm{mM} \mathrm{KCl}, 20 \mathrm{mM} \mathrm{MgSO}_{4}, 2 \mathrm{mM} \mathrm{DTE}, 4 \mu \mathrm{M}$ resazurin, $\left.\mathrm{pH} 7.0\right)$ with $\mathrm{H}_{2}+\mathrm{CO}_{2}\left(80: 20 \%, 2 \times 10^{5} \mathrm{~Pa}\right)$. b $50 \mathrm{mM}$ or c $300 \mathrm{mM} \mathrm{KHCO}_{3}$ were added to the cell suspensions before the experiment was started by replacing the gas phase. Squares, acetic acid; triangles, formic acid 


\section{Inhibitory effect of bicarbonate on ATP synthesis}

To analyze the effect of bicarbonate on the energy metabolism of T. kivui in detail, the cellular ATP content of resting cells was measured in the presence or absence of bicarbonate (Fig. 4a). Therefore, cells were incubated in buffer with $\mathrm{H}_{2}+\mathrm{CO}_{2}$ as substrate, increasing bicarbonate concentrations were added and the ATP content was measured over time. As seen in Fig. 4a, the ATP content dropped immediately to zero if $300 \mathrm{mM}$ bicarbonate was present in the cell suspensions. At $50 \mathrm{mM}$ bicarbonate, there was also a decrease in the intracellular ATP content, but only by $62 \%$. Next, we investigated the effect of bicarbonate on the activity of the membrane-bound ATPase in T. kivui (Fig. 4b). After the preparation of membranes, ATP hydrolysis was measured in the presence or absence of bicarbonate. Indeed, ATP hydrolysis as catalyzed by membranes $(138 \mathrm{mU} / \mathrm{mg}$ ) was inhibited by $81 \%$ by $300 \mathrm{mM} \mathrm{NaHCO}$. The same was observed with $\mathrm{KHCO}_{3}$. Additionally, we examined the ability of ATP synthesis by cell suspensions of $T$. kivui with an artificial $\Delta \mathrm{pH}$ over the membrane as driving force (Additional file 1: Figure S1). In this experiment, resting cells were incubated in the presence or absence of $300 \mathrm{mM}$ $\mathrm{KHCO}_{3}$ and then $\mathrm{HCl}$ was added to induce a $\Delta \mathrm{pH}$ across the membrane. At a $\Delta \mathrm{pH}$ of 6 , ATP was synthesized to $3.2 \mathrm{nmol} \mathrm{mg}$ protein. In contrast, when cells were incubated with $300 \mathrm{mM} \mathrm{KHCO}$, ATP was only synthe-

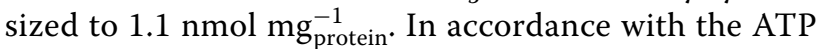
hydrolysis experiments, only $34 \%$ of the ATP was synthesized in the presence of bicarbonate. Overall, these experiments could be interpreted to mean that the ATP synthase is inhibited by bicarbonate.

A possible $\mathrm{pH}$ effect by the addition of bicarbonate to the cell suspension was excluded. Therefore, the $\mathrm{pH}$ was adjusted in the control experiments with $\mathrm{KOH}$ to the same $\mathrm{pH}$ as in cell suspensions with additional $300 \mathrm{mM}$ bicarbonate. The change in $\mathrm{pH}$ from 7.0 to 8.2 by the addition of $\mathrm{KOH}$ did not result in the same formate production. Only $14 \mathrm{mM}$ of formate was formed after $90 \mathrm{~min}$ (data not shown).

\section{Characterization of hydrogen-dependent $\mathrm{CO}_{2}$ reduction by whole cells}

After the discovery that bicarbonate completely inhibits further downstream processing of formate, formate production from $\mathrm{H}_{2}+\mathrm{CO}_{2}$ was studied in detail in the presence of $300 \mathrm{mM} \mathrm{KHCO}_{3}$. The cells showed highest specific formate production rates of $220 \mathrm{mmol} \mathrm{g}_{\text {protein }}^{-1} \mathrm{~h}^{-1}$ (143 mmol g $\mathrm{gDW}^{-1} \mathrm{~h}^{-1}$ ) at a temperature of $60{ }^{\circ} \mathrm{C}$ (Fig. 5a). Nevertheless, even at moderate reaction temperature of $30{ }^{\circ} \mathrm{C}$, there was still a catalytic activity of $58 \mathrm{mmol}$ $\mathrm{g}_{\text {protein }}^{-1} \mathrm{~h}^{-1}\left(38 \mathrm{mmol} \mathrm{g}_{\mathrm{CDW}}^{-1} \mathrm{~h}^{-1}\right)$. Moreover, an increase of the specific formate production rate up to $234 \mathrm{mmol}$ $\mathrm{g}_{\text {protein }}^{-1} \mathrm{~h}^{-1}\left(152 \mathrm{mmol} \mathrm{g} \mathrm{gDW}^{-1} \mathrm{~h}^{-1}\right)$ was observed at a cell concentration of $0.5 \mathrm{mg} \mathrm{mL}^{-1}$ (Fig. 5b). Increasing cell densities resulted in a linear increase of the volumetric formate production rates up to $270 \mathrm{mmol} \mathrm{L}^{-1} \mathrm{~h}^{-1}$ at $4 \mathrm{mg} \mathrm{mL}^{-1}$. Simultaneously, the specific rates decreased.

Thermoanaerobacter kivui is a promising organism for industrial applications, since it can grow on syngas/ $\mathrm{CO}$ in mineral medium without the requirement for
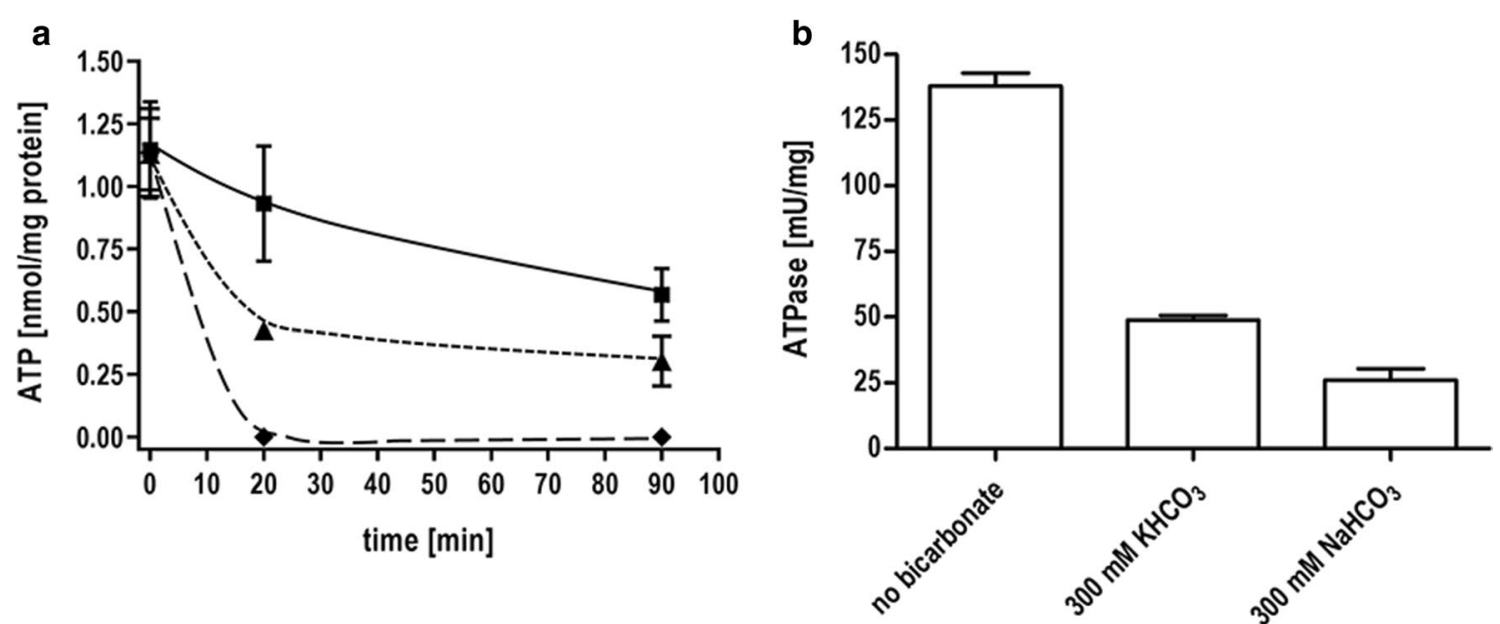

Fig. 4 Effect of bicarbonate on the ATP content of resting cells and ATP hydrolysis catalyzed by membranes of T. kivui. a Resting cells of T. kivui $\left(1 \mathrm{mg} / \mathrm{mL}\right.$ ) were incubated in anoxic buffer $\left(50 \mathrm{mM}\right.$ Imidazole, $20 \mathrm{mM} \mathrm{KCl}, 20 \mathrm{mM} \mathrm{MgSO}{ }_{4}, 2$ mM DTE, $4 \mu \mathrm{M}$ Resazurin, $\left.\mathrm{pH}_{7,0}\right)$ with $\mathrm{H}_{2}+\mathrm{CO}_{2}(80: 20 \%$, $2 \times 10^{5} \mathrm{~Pa}$ ) in the absence or presence of $\mathrm{KHCO}_{3}$ and the ATP content of cells were determined. Squares, without bicarbonate; triangles, $50 \mathrm{mM}$ $\mathrm{KHCO}_{3}$; diamonds, $300 \mathrm{mM} \mathrm{KHCO}_{3}$. b Membranes from T. kivui were incubated for $3 \mathrm{~min}$ in the presence $\left(300 \mathrm{mM} \mathrm{KHCO} \mathrm{Or}_{3} 300 \mathrm{mM} \mathrm{NaHCO}_{3}\right.$ ) or absence of bicarbonate in buffer (100 mM Tris/HCl, 20 mM MgSO $, 20 \mathrm{mM} \mathrm{KCl}, \mathrm{pH} 7.0)$ and the ATP hydrolysis of membranes was determined 
a

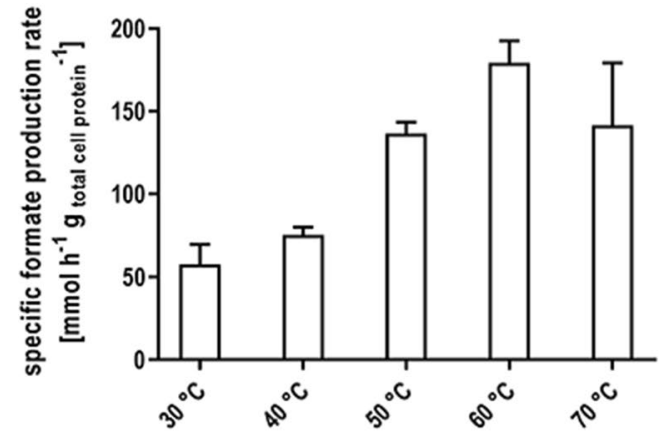

b

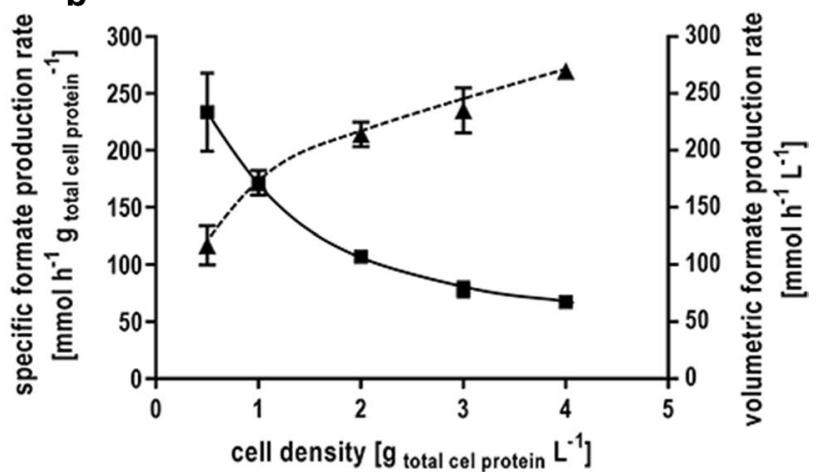

Fig. 5 Characterization of hydrogen-dependent $\mathrm{CO}_{2}$ reduction by whole cells of $T$. kivui. a Resting cells of $\mathrm{T}$. kivui (1 mg/mL) were incubated in anoxic buffer (50 mM Imidazole, $20 \mathrm{mM} \mathrm{KCl}, 20 \mathrm{mM} \mathrm{MgSO}_{4}, 2 \mathrm{mM} \mathrm{DTE}, 4 \mu \mathrm{M}$ Resazurin, pH 7.0) with $\mathrm{H}_{2}+\mathrm{CO}_{2}\left(80: 20 \%, 2 \times 10^{5} \mathrm{~Pa}\right)$ in the presence of $300 \mathrm{mM} \mathrm{KHCO}_{3}$. Shown is the temperature profile for formate production by whole cells at the temperature indicated. $\mathbf{b}$ The influence of the cell density on formate production by resting cells was determined by applying a final concentration of $0.5-4 \mathrm{mg} \mathrm{mL}^{-1}$ in anoxic serum bottles at a temperature of $60{ }^{\circ} \mathrm{C} .300 \mathrm{mM} \mathrm{KHCO}_{3}$ was added to the cell suspension and the experiments were started by replacing the gas phase with $\mathrm{H}_{2}+\mathrm{CO}_{2}$ $\left(80: 20 \%, 2 \times 10^{5} \mathrm{~Pa}\right)$. The initial formate production rates (squares) and the volumetric production rates (triangle) were plotted against the cell density used in the experiment

yeast extract and additional vitamins [22, 28]. Therefore, we investigated the specific formate production rate of resting cells that were grown on mineral medium with pyruvate or glucose as growth substrate (Additional file 1: Figure S2). No differences in the specific formate production rates were observed if the complex medium was replaced by defined mineral medium in the cultivation process. Glucose-grown cells (in mineral medium) showed a slight decrease of $33 \%$ in the specific formate production rate compared to pyruvate grown cells.

\section{Syngas conversion to formate}

Syngas is an increasingly considered "green" option for the production of chemicals and biofuels [1] and T. kivui was already shown to grow on $\mathrm{CO}$ or syngas [22]. To analyze whether syngas is converted to formate, cells were grown on $50 \% \mathrm{CO}$ and cell suspensions were prepared. A syngas mixture of $\mathrm{H}_{2}(26 \%), \mathrm{CO}_{2}(11 \%)$ and $\mathrm{CO}(63 \%)$ was used as substrate. The gas consumption in the head space of the serum bottles was monitored by gas chromatography. In the absence of bicarbonate, resting cells converted syngas to acetate (Fig. 6a, b). Notably, the CO concentration decreased by $99 \mathrm{mM}$. At the same time, $\mathrm{H}_{2}$ and $\mathrm{CO}_{2}$ increased by only 26 and $74 \mathrm{mM}$, indicating that $\mathrm{CO}$ and $\mathrm{H}_{2}$ were used as reductant for $\mathrm{CO}_{2}$. If additional bicarbonate was added to the cell suspension, the product spectrum changed and mainly formate was produced in high titers up to $130 \mathrm{mM}$ (Fig. 6c, d). The specific formate production rate was $8 \mathrm{mmol} \mathrm{g}_{\text {protein }}^{-1} \mathrm{~h}^{-1}$ $\left(5 \mathrm{mmol} \mathrm{g} \mathrm{g}_{\mathrm{CDW}}^{-1} \mathrm{~h}^{-1}\right)$. CO was almost completely used up but the hydrogen level remained almost the same. This indicates that $\mathrm{H}_{2}$ is not oxidized in the presence of $\mathrm{CO}$ and an alternative electron donor seems to be used for the reduction of $\mathrm{CO}_{2}$ to formate. Additionally, a clear increase in the $\mathrm{CO}_{2}$ concentration was detectable, provoked by the interconversion of $\mathrm{HCO}_{3}{ }^{-}$to $\mathrm{CO}_{2}$. This is the first demonstration that syngas can be converted exclusively to formate by an acetogenic bacterium. $T$. kivui cells which were not adapted on $\mathrm{CO}$, instead grown heterotrophic with pyruvate as substrate, showed only a little formation of acetate and almost no formate was produced in the presence of bicarbonate.

\section{Formate production in closed-batch fermentation}

Next, we wanted to establish a production platform for formate in closed-batch fermentation (Fig. 7). Here, $T$. kivui cells were grown in defined mineral medium with $28 \mathrm{mM}$ glucose as substrate $\left(t_{\mathrm{D}}=3.2 \mathrm{~h}\right)$ to an optical density of $\sim 0.3$. Then, bicarbonate, $\mathrm{H}_{2}+\mathrm{CO}_{2}$ or a combination of both were added. The addition of bicarbonate led to an immediate growth arrest and stop of acetate formation. By adding $\mathrm{H}_{2}+\mathrm{CO}_{2}$, the optical density did not increase but cells produced more acetate. Formate was not produced overall. Now, when bicarbonate and $\mathrm{H}_{2}+\mathrm{CO}_{2}$ were added, growth as well as acetate formation was completely abolished, but cells started to produce formate. The specific rate of formate production was $96 \mathrm{mmol} \mathrm{g}_{\text {protein }}^{-1} \mathrm{~h}^{-1}\left(62 \mathrm{mmol} \mathrm{g} \mathrm{g}_{\mathrm{CDW}}^{-1} \mathrm{~h}^{-1}\right)$. Finally, up to $50 \mathrm{mM}$ formate was produced in the cultivation broth.

\section{Discussion}

Resting cells of T. kivui were proven in this study as highly efficient whole-cell biocatalysts for the direct hydrogenation of $\mathrm{CO}_{2}$ to formate with remarkable catalytic 

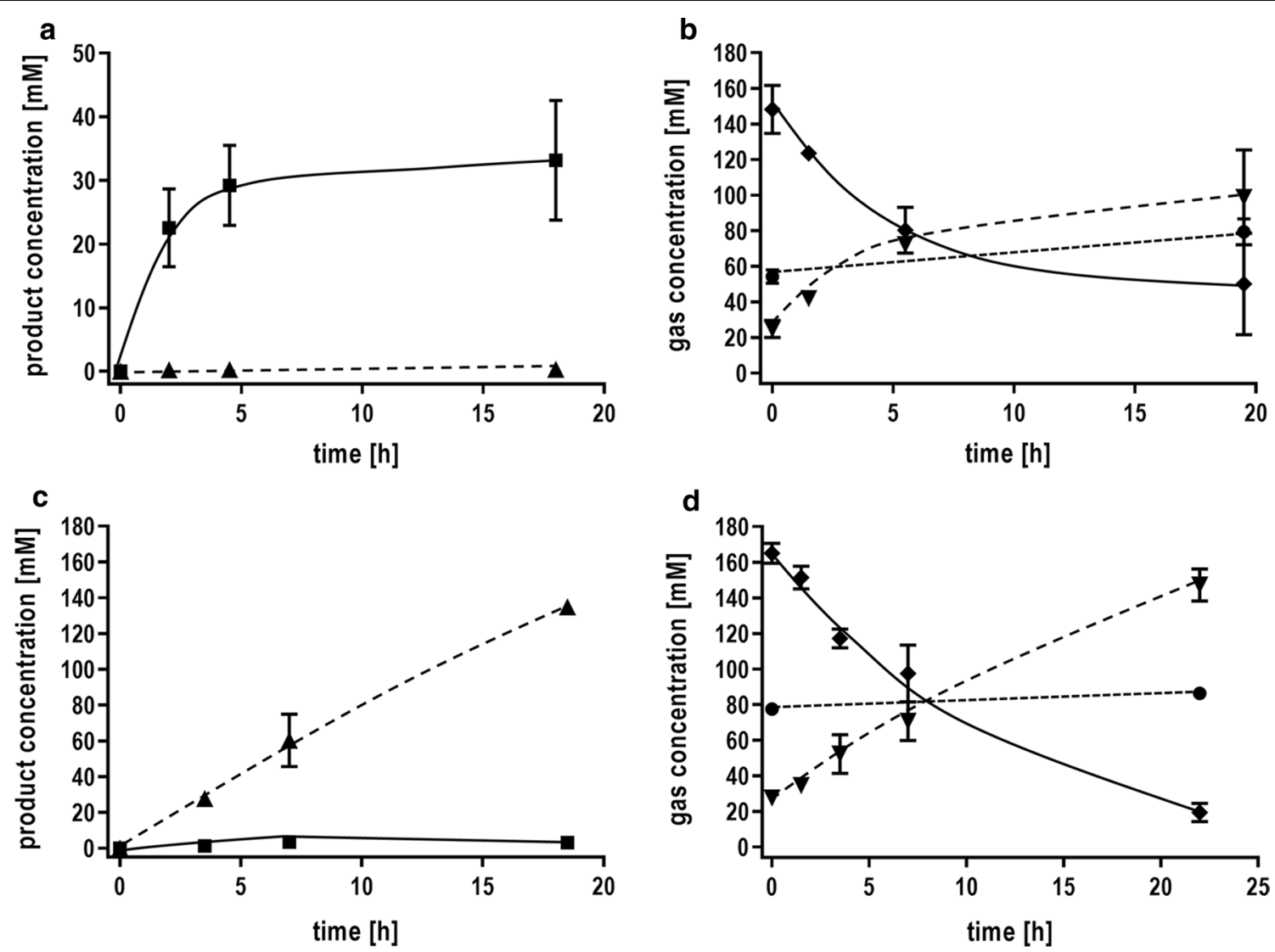

Fig. 6 Formate production from syngas using whole cells of T. kivui. Cells were grown on $50 \%$ CO in complex medium, harvested in the end-exponential growth phase and suspended in buffer (50 mM Imidazole, $20 \mathrm{mM} \mathrm{KCl}, 20 \mathrm{mM} \mathrm{MgSO}{ }_{4}, 2 \mathrm{mM} \mathrm{DTE}, 4 \mu \mathrm{M}$ Resazurin, pH 7,0) to a final concentration of $1 \mathrm{mg} / \mathrm{mL}$ in anoxic serum bottles. The experiment was started by replacing the gas phase with a mixture of $\mathrm{H}_{2}+\mathrm{CO}_{2}+\mathrm{CO}$ $\left(26: 11: 63 \%, 2 \times 10^{5} \mathrm{~Pa}\right) \mathbf{a}, \mathbf{b}$ in the absence of bicarbonate and $\mathbf{c}, \mathbf{d}$ in the presence of $300 \mathrm{mM} \mathrm{KHCO}_{3}$. The product formation in liquid (a), $\mathbf{c}$ and the gas consumption in the head space $(\mathbf{b}, \mathbf{d})$ is shown over time. Squares, acetic acid; triangles, formic acid; diamonds, $\mathrm{CO}$; triangles down, $\mathrm{CO}_{2}$; circles, $\mathrm{H}_{2}$

activities. In addition, we showed the first whole-cell approach for the exclusive conversion of syngas to formate using an acetogenic bacterium. The recently identified hydrogen-dependent $\mathrm{CO}_{2}$ reductase (HDCR) [13] is the key enzyme in whole cell of T. kivui used as microbial cell factories for hydrogen storage, $\mathrm{CO}_{2}$ capturing and syngas conversion to formate.

Since the K value for Eq. 1

$$
\mathrm{H}_{2}+\mathrm{CO}_{2} \Leftrightarrow \mathrm{HCOO}^{-}+\mathrm{H}^{+} \quad \Delta G^{0^{\prime}}=3.5 \mathrm{kJmol}^{-1}
$$

is close to one, the chemical equilibrium can be easily controlled by small variations in $\mathrm{pH}$, pressure and substrate/product concentrations. High concentrations of formate will favor the backwards reaction. An alkaline environment serves as proton scavenger and therefore pulls the reaction to the product side. The favored formate formation from $\mathrm{H}_{2}+\mathrm{CO}_{2}$ in a more alkaline environment was also observed in a whole-cell system for hydrogen-dependent $\mathrm{CO}_{2}$ reduction based on E. coli [29]. By the addition of bicarbonate to resting cells, the available amount of $\mathrm{CO}_{2}$ in solution was increased and the reaction was pushed towards product formation. Since formate dehydrogenases of the Mo/W-bis PGD family are known to use only $\mathrm{CO}_{2}$ and not bicarbonate as substrate [12], we inspected the genome of T. kivui to identify a putative carbonic anhydrase (CA) which catalyzes the rapid interconversion of $\mathrm{HCO}_{3}{ }^{-}$and $\mathrm{CO}_{2}$, and found one gene annotated as putative carbonic anhydrase/ acetyltransferase (TKV_c11400). Consistent with this, cell extracts of T. kivui had specific CA activity of $0.17 \mathrm{U} /$ mg [30].

Bicarbonate was identified here as an inhibitor of ATP synthesis. The inhibition of bacterial $F_{1} F_{0}$ ATP synthases by bicarbonate is not a common feature, but the effect was already described in literature [31, 32]. The effect of different anions like sulfite, azide and bicarbonate on the ATPase activity of membrane-bound $F_{1} F_{0}$ is known 

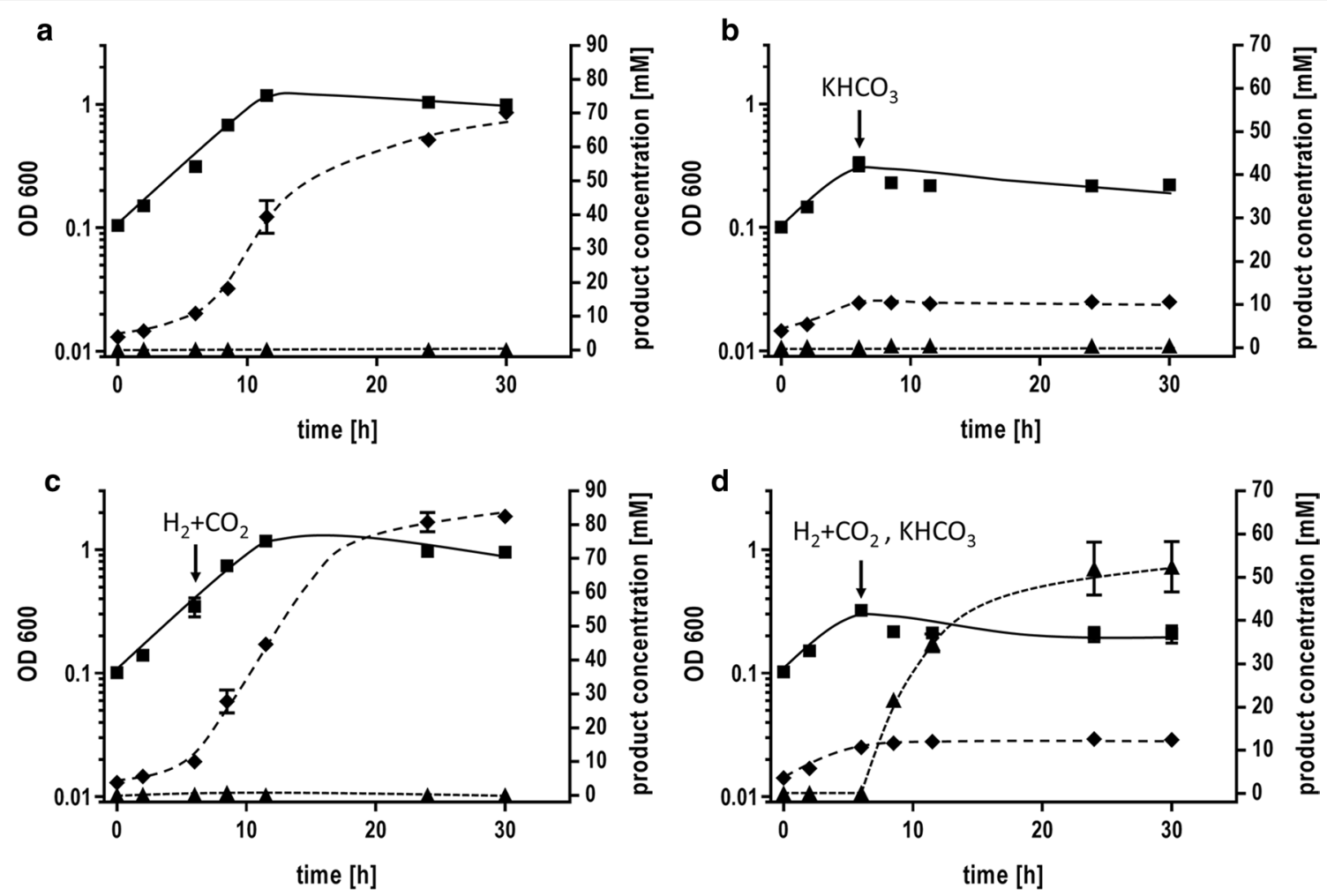

Fig. 7 Closed-batch fermentation for hydrogen-dependent $\mathrm{CO}_{2}$ reduction to formic acid. a T. kivui was grown on $28 \mathrm{mM}$ glucose in a defined mineral medium in a shaking water bath at $66^{\circ} \mathrm{C}$. At the time point indicated $\mathbf{b} 300 \mathrm{mM} \mathrm{KHCO}_{3}, \mathbf{c} \mathrm{H}_{2}+\mathrm{CO}_{2}\left(80: 20 \%, 2 \times 10^{5} \mathrm{~Pa}\right)$ or $\mathbf{d} \mathrm{H}_{2}+\mathrm{CO}_{2}$ $\left(80: 20 \%, 2 \times 10^{5} \mathrm{~Pa}\right)+300 \mathrm{mM} \mathrm{KHCO}_{3}$ were added to the growing culture. The optical density of the culture was between 0.3 and 0.4 . Squares, $\mathrm{OD}_{600}$; diamonds, acetic acid; triangles, formic acid

for decades but a detailed understanding of the mechanism of action of the activating anions is still missing and a matter of controversy [33-36]. In our study potassium bicarbonate could be replaced by sodium bicarbonate, indeed indicating an inhibitory effect of the anion $\mathrm{HCO}_{3}{ }^{-}$. Lodeyro et al. concluded in their study [32] that the anion bicarbonate competes with the binding of ADP to a low-affinity binding site instead of binding to a $P_{i}$ site in the $F_{1}$ subunit. They postulated that ATP hydrolysis and inhibition of ATP synthesis was affected by bicarbonate by modulating the relative affinities of the catalytic site for ATP and ADP. Since anions like bicarbonate and acid were shown to bind to different sites on the mitochondrial $\mathrm{F}_{1}$ subunit, further studies for the direct identification of the $\mathrm{HCO}_{3}^{-}$binding site on the $\mathrm{F}_{1} \mathrm{~F}_{0}$ ATP synthase of $T$. kivui have to be done. Purification and characterization of this enzyme could help to finally elucidate the mechanism and site of action of bicarbonate.

Whole-cell biocatalysis for the production of formate from the greenhouse gas $\mathrm{CO}_{2}$ and the energy carrier $\mathrm{H}_{2}$ was also observed in other biological systems [14, 29, 37]. Besides the acetogenic bacteria $A$. woodii and T. kivui, the well-known model organism $E$. coli was also used as a cell factory for the hydrogenation of $\mathrm{CO}_{2}$ [29]. The key enzyme in $E$. coli to catalyze $\mathrm{H}_{2}+\mathrm{CO}_{2}$ conversion to formate is the membrane-bound formate hydrogen lyase (FHL) complex [18, 38]. But this enzyme is designed by nature to produce $\mathrm{H}_{2}$ and $\mathrm{CO}_{2}$ from formate under fermentative conditions and therefore, the catalytic rates for formate formation are pretty low and harsh conditions are required for the reaction. In a $\mathrm{pH}$-controlled and highly pressurized reactor system (up to 10 bar overpressure), the specific formate production rates were $15 \mathrm{mmol} \mathrm{g}_{\mathrm{CDW}}^{-1} \mathrm{~h}^{-1}$ [29]. This is only a small fraction of the activity of whole cells from T. kivui at moderate conditions of 30 or $60{ }^{\circ} \mathrm{C}$ with one bar overpressure. Here, the cells showed specific formate production rates of $58 \mathrm{mmol} \mathrm{g}_{\text {protein }}^{-1} \mathrm{~h}^{-1}\left(38 \mathrm{mmol} \mathrm{g}_{\mathrm{CDW}}^{-1} \mathrm{~h}^{-1}\right)$ and $220 \mathrm{mmol}$ $\mathrm{g}_{\text {protein }}^{-1} \mathrm{~h}^{-1}\left(143 \mathrm{mmol} \mathrm{g}_{\mathrm{CDW}}^{-1} \mathrm{~h}^{-1}\right)$, respectively, qualifying T. kivui for applications at high and moderate reaction temperatures. Nevertheless, the thermophilic acetogenic bacterium T. kivui showed the highest specific formate production rates of $234 \mathrm{mmol} \mathrm{g}_{\text {protein }}^{-1} \mathrm{~h}^{-1}(152 \mathrm{mmol}$ $\mathrm{g}_{\mathrm{CDW}}^{-1} \mathrm{~h}^{-1}$ ) ever reported in biological systems (Table 1 ).

Furthermore, the volumetric formate production rates of $270 \mathrm{mmol} \mathrm{L}^{-1} \mathrm{~h}^{-1}$ at cell concentrations of $4 \mathrm{mg} \mathrm{mL}^{-1}$ 
Table 1 Whole-cell biocatalysis for hydrogen-dependent $\mathrm{CO}_{2}$ reduction to formate in closed-batch conditions

\begin{tabular}{|c|c|c|c|c|c|}
\hline Organism & $\begin{array}{l}\text { Reaction condition: } \\
\text { temperature }\left({ }^{\circ} \mathrm{C}\right)\end{array}$ & $\begin{array}{l}\text { Reaction condition: } \\
\text { overpressure ( } \mathrm{MPa} \text { ) }\end{array}$ & Mode & $\begin{array}{l}\text { Specific formate production } \\
\text { rate }\left(\mathrm{mmol} \mathrm{g}_{\mathrm{CDW}}^{-1} \mathrm{~h}^{-1}\right)\end{array}$ & Refs. \\
\hline E. coli (WT) & 37 & 10 & Closed-batch bioreactor $^{a}$ & $\sim 15$ & [29] \\
\hline E. coli (rec. strain $\left.{ }^{b}\right)$ & 37 & - & Closed-batch (flasks) & $\sim 0.1$ & {$[37]$} \\
\hline $\begin{array}{l}\text { Desulfovibrio desulfuri- } \\
\text { cans (WT) }\end{array}$ & 37 & 1 & Closed-batch (flasks) & $\sim 0.7$ & [39] \\
\hline A. woodii (WT) & 30 & 1 & Closed-batch (flasks) & $\sim 22$ & [14] \\
\hline \multirow[t]{2}{*}{ T. kivui (WT) } & 30 & 1 & Closed-batch (flasks) & $\sim 38$ & This study \\
\hline & 60 & 1 & Closed-batch (flasks) & $\sim 152$ & This study \\
\hline
\end{tabular}

is not an insignificant economical factor: implementing high cell densities in a later fermentation process is considered to be one of the most effective ways for enhancing the productivity [40]. Efficient cell recycling and cell retention systems with optimized conditions for the accumulation of high cell densities up to $200 \mathrm{~g} / \mathrm{L}$ were already implemented in bioprocesses [41-43].

The fermentation of syngas into biofuels and biochemicals using acetogenic bacteria has attracted more and more interest over the last few years and some acetogens were already implemented in this process [44-47]. Since the syngas composition depends strongly on the kind of gasifier and the kind and condition of the feedstock used, there is no "universal" composition of syngas. But it was already shown that $T$. kivui can be adapted to a carboxydotrophic lifestyle by a stepwise adaptation on increasing $\mathrm{CO}$ concentrations, up to $100 \% \mathrm{CO}$ [22]. A detailed understanding of the $\mathrm{CO}$ metabolism in T. kivui is still missing. Since $\mathrm{CO}$ is a potent inhibitor of the active site of [FeFe]-hydrogenases [48-50], the HDCR hydrogenase subunit should be inactive and no formate should be formed. The inhibitory effect of CO on the HDCR hydrogenase activity of $A$. woodii was already described [14]. However, reduced ferredoxin can serve as an alternative electron donor for the reduction of $\mathrm{CO}_{2}$ to formate in in vitro studies. This correlates with the finding that $\mathrm{H}_{2}$ was not utilized by T. kivui in the previous syngas experiment if $\mathrm{CO}$ was present but formate was still produced. Therefore, the two annotated $\mathrm{CO}$ dehydrogenases genes in the genome of T. kivui could play a key role in the oxidation of $\mathrm{CO}$ to $\mathrm{CO}_{2}$ with simultaneous reduction of ferredoxin, which is subsequently used by the HDCR for a ferredoxin-driven $\mathrm{CO}_{2}$ reduction to formate.

In this study, we showed the feasibility of two approaches for the efficient conversion of $\mathrm{H}_{2}+\mathrm{CO}_{2}$ to formate: whole-cell biocatalysis and closed-batch bioprocess/fermentation. But the production rates as well as the finally produced formate concentration differed between the two approaches. The reasons could be diverse and are probably linked to $\mathrm{pH}$, buffer capacity, feedback inhibition, etc. The applicability of growing cells as microbial cell factories has to be proven in further fermentation studies. Nevertheless, the addition of bicarbonate and $\mathrm{H}_{2}+\mathrm{CO}_{2}$ can switch the growing culture to the production of formate instead of acetate. The gases $\mathrm{H}_{2}+\mathrm{CO}_{2}$ can also serve in the first phase as growth substrate till the production phase is initiated. In this production phase, $\mathrm{H}_{2}+\mathrm{CO}_{2}$ act as reactants for the efficient production of formate. Whether the minimized cost-intensive and time-consuming work flow in a closed-batch fermentation can rebalance the increasing downstream costs due to the accumulation of unwanted metabolic side products (e.g., acetate) in the fermentation broth during the growth phase has to be considered and individually calculated.

\section{Conclusion}

This work demonstrates an efficient whole-cell approach for the production of formate from $\mathrm{H}_{2}+\mathrm{CO}_{2}$ or syngas using the thermophilic acetogen T. kivui. Bicarbonate seems to be an efficient inhibitor of the ATP synthase of this organism, thus preventing further downstream conversion of formate to acetate, resulting in high titers of the desired end product. T. kivui catalyzed the hydrogen-dependent $\mathrm{CO}_{2}$ reduction with remarkable catalytic activities at elevated and ambient temperatures. Its thermophilic nature and the autotrophic growth properties on mineral medium qualify this organism for future fermentation approaches to address the process on a larger scale and to investigate the stability of the whole-cell system. 


\section{Methods}

\section{Organism and cultivation}

Thermoanaerobacter kivui LKT-1 (DSM 2030) was cultivated at $66{ }^{\circ} \mathrm{C}$ under anaerobic conditions in complex and defined mineral medium [22]. Media were prepared under anoxic conditions as described before [51, 52]. Glucose $(28 \mathrm{mM})$, pyruvate $(100 \mathrm{mM})$ or CO $(50 \% \mathrm{CO}$, $40 \% \mathrm{~N}_{2}$ and $10 \% \mathrm{CO}_{2}[\mathrm{v} / \mathrm{v}]$ at $\left.2 \times 10^{5} \mathrm{~Pa}\right)$ were used as growth substrate. Cell were cultivated in 1-L flasks (Müller-Krempel, Bülach, Switzerland) containing $500 \mathrm{~mL}$ or $200 \mathrm{~mL}$ medium in the case of autotrophic cultivation. Growth was determined by measuring the optical density at $600 \mathrm{~nm}$ with an UV/Vis spectrophotometer.

\section{Preparation of resting cells and cell suspension experiments}

For the preparation of resting cells, T. kivui was cultivated in 1-L flasks (Müller-Krempel, Bülach, Switzerland) in the above-mentioned growth media to the late exponential growth phase. Glucose- and fructose-grown cells were harvested at an $\mathrm{OD}_{600}$ of 1.7-2.0, CO-grown cells were harvested at $\mathrm{OD}_{600}$ of 0.6. The culture was centrifuged under anoxic conditions at $11,500 \mathrm{~g}$ and $4{ }^{\circ} \mathrm{C}$ for $10 \mathrm{~min}$ and was washed twice in imidazole puffer $(50 \mathrm{mM}$ imidazole-HCl, $20 \mathrm{mM} \mathrm{MgSO}_{4}, 20 \mathrm{mM} \mathrm{KCl,} 2 \mathrm{mM}$ DTE, $4 \mu \mathrm{M}$ resazurin, $\mathrm{pH} 7.0$ ). Afterwards, the cells were resuspended, if not otherwise stated, in the same buffer to a protein concentration of $1 \mathrm{mg} / \mathrm{mL}$ and kept in gas-tight Hungate tubes. All preparation steps were performed under strictly anoxic conditions at room temperature in an anaerobic chamber (Coy Laboratory Products, Grass Lake, MI) as described [53]. The protein concentration of the cell suspension was determined according to [54] and the cells were directly used for the subsequent cell suspension experiments.

To determine the conversion of $\mathrm{H}_{2}+\mathrm{CO}_{2}$ in cell suspension experiments, the 120-mL serum flasks (Glasgerätebau Ochs $\mathrm{GmbH}$, Bovenden-Lenglern, Germany) contained pre-warmed buffer under a $\mathrm{N}_{2}$ atmosphere, incubated with cell suspensions for $10 \mathrm{~min}$ at $60{ }^{\circ} \mathrm{C}$. Subsequently, bicarbonate $\left(\mathrm{KHCO}_{3}\right.$ or $\left.\mathrm{NaHCO}_{3}\right)$ was added and the gas phase of the serum flasks was changed to $2 \times 10^{5} \mathrm{~Pa} \mathrm{H}_{2}+\mathrm{CO}_{2}(80: 20[\mathrm{v} / \mathrm{v}])$. When syngas was the substrate, the reaction was started by replacing the head space of the serum flasks with a gas composition of $26 \% \mathrm{H}_{2}+11 \% \mathrm{CO}_{2}+63 \% \mathrm{CO}$ [v/v] at $2 \times 10^{5} \mathrm{~Pa}$. Ionophores and uncoupling agents such as 3,3,4,5-tetrachlorosalicylanilide (TCS, dissolved in EtOH), $N, N, N^{\prime}, N^{\prime}$-tetracyclohexyl-1,2phenylenedioxydiacetamide (ETH2120, dissolved in $\mathrm{EtOH}$ ), gramicidin (dissolved in $\mathrm{EtOH}$ ) and
$N, N^{\prime}$-dicyclohexylcarbodiimide (DCCD, dissolved in $\mathrm{EtOH}$ ) were added $10 \mathrm{~min}$ prior to the reaction start. The serum flasks contained a final volume of $10 \mathrm{~mL}$ buffer in all the experiments. Samples were taken and ATP [55], acetate, formate, $\mathrm{H}_{2}, \mathrm{CO}_{2}$ and $\mathrm{CO}$ were determined as described before [13, 22].

\section{Preparation of membranes and measurement of ATP hydrolysis activity}

Cells were grown in $500 \mathrm{~mL}$ complex medium in 1-L flasks (Glasgerätebau Ochs, Bovenden-Lenglern, Germany) with $100 \mathrm{mM}$ pyruvate as carbon source to an optical density at $600 \mathrm{~nm}$ of 1.7-2.0. The cells were harvested under toxic conditions at $11,500 \mathrm{~g}$ for $10 \mathrm{~min}$ at $4{ }^{\circ} \mathrm{C}$, were washed twice in buffer $\mathrm{A}(50 \mathrm{mM}$ imidazole- $\mathrm{HCl}, 20 \mathrm{mM} \mathrm{MgSO}, 20 \mathrm{mM} \mathrm{KCl}, \mathrm{pH}$ 7.0) and membranes were prepared as described before [26]. The protein concentration was determined as described [56] and the membranes were directly used to measure ATP hydrolysis.

For the determination of the ATP hydrolysis, membranes $(200 \mu \mathrm{g})$ were resuspended in buffer B $(100 \mathrm{mM}$ Tris/ $\mathrm{HCl}, 20 \mathrm{mM} \mathrm{MgSO}, 20 \mathrm{mM} \mathrm{KCl}, \mathrm{pH}$ 7.0) to a final volume of $1200 \mu \mathrm{L}$ and incubated at $60{ }^{\circ} \mathrm{C}$ for $3 \mathrm{~min}$ in the presence or absence of $300 \mathrm{mM} \mathrm{KHCO}_{3}$. After addition of $2.5 \mathrm{mM} \mathrm{Na} \mathrm{m}_{2} \mathrm{ATP}$, samples $(200 \mu \mathrm{L})$ were taken at defined time points and the ATP content was determined as described [55].

\section{Closed-batch fermentation}

Thermoanaerobacter kivui was grown at $66{ }^{\circ} \mathrm{C}$ in $50 \mathrm{~mL}$ mineral medium in $120 \mathrm{~mL}$ serum flasks (Glasgerätebau Ochs GmbH, Bovenden-Lenglern, Germany) with $28 \mathrm{mM}$ glucose as growth substrate and a gas phase of $\mathrm{N}_{2}+\mathrm{CO}_{2}(80: 20[\mathrm{v} / \mathrm{v}])$. At $\mathrm{OD}_{600} 0.3-0.4$ the growing cells were switched into the formate production phase by addition of $300 \mathrm{mM} \mathrm{KHCO}_{3}$ and by changing the gas phase to a $\mathrm{H}_{2}+\mathrm{CO}_{2}(80: 20 \%$ [v/v]) atmosphere. Samples for the product determination were taken with a syringe.

\section{Determination of cell dry weight}

For cell dry weight determination of $T$. kivui, three independent cultures were grown in complex medium with $0.1 \mathrm{M}$ pyruvate as growth substrate. At three different optical densities in the exponential growth phase the culture was harvested $\left(4150 \mathrm{~g}, 30 \mathrm{~min}, 4{ }^{\circ} \mathrm{C}\right)$ in technical triplicates $(3 \times 50 \mathrm{~mL})$. Afterwards, the cell pellet was frozen in liquid $\mathrm{N}_{2}$ and dried by lyophilisation over $24 \mathrm{~h}$. The dried samples were weighted and the cell dry weight (CDW) was calculated to $0.379 \mathrm{mg} / \mathrm{mL}$ at $\mathrm{OD}_{600}$ of 1 . 


\section{Supplementary information}

Supplementary information accompanies this paper at https://doi. org/10.1186/s13068-020-1670-x.

Additional file 1: Figure S1. ATP synthesis by cell suspensions of $T$. kivui driven by an artificial $\Delta \mathrm{pH}$. Cells were grown with $0.1 \mathrm{M}$ pyruvate, harvested in the end-exponential growth phase and suspended in buffer (50 mM Imidazole, 20 mM KCl, 20 mM MgSO, 2 mM DTE, 4 HM Resazurin, $\mathrm{pH}$ 7.0). Cell suspensions ( $1 \mathrm{mg} / \mathrm{mL})$ were incubated with and without $\mathrm{KHCO}_{3}$ for 10 min in buffer $(25 \mathrm{mM}$ Tris/ $\mathrm{HCl}, 20 \mathrm{mM} \mathrm{MgCl}, \mathrm{pH} 9.0)$ at $60{ }^{\circ} \mathrm{C}$. At the time point indicated (arrow), $\mathrm{HCl}$ was added to the cell suspensions. Shown are data from one representative experiment out of two independent replicates. Squares, without $\mathrm{KHCO}_{3}$; triangles, $300 \mathrm{mM}$ $\mathrm{KHCO}_{3}$.

Additional file 2: Figure S2. Specific formate production rates of resting cells from T. kivui grown on mineral medium. Cells were grown with $28 \mathrm{mM}$ glucose or $0.1 \mathrm{M}$ pyruvate in a defined mineral or complex medium, harvested in the end-exponential growth phase and suspended in buffer $\left(50 \mathrm{mM}\right.$ Imidazole, $20 \mathrm{mM} \mathrm{KCl}, 20 \mathrm{mM} \mathrm{MgSO}{ }_{4}, 2 \mathrm{mM}$ DTE, $4 \mu \mathrm{M}$ Resazurin, $\mathrm{pH} 7.0$ ) to a final concentration of $1 \mathrm{mg} / \mathrm{mL}$ in anoxic serum bottles. The bottles were incubated in a shaking water bath for $10 \mathrm{~min}$ at $60{ }^{\circ} \mathrm{C}$ with additional $300 \mathrm{mM} \mathrm{KHCO}_{3}$. The experiment was started by replacing the gas phase with $\mathrm{H}_{2}+\mathrm{CO}_{2}\left(80: 20 \%, 2 \times 10^{5} \mathrm{~Pa}\right)$. MM mineral medium, CM complex medium.

\section{Abbreviations}

LOHC: Liquid organic hydrogen carrier; HDCR: Hydrogen-dependent $\mathrm{CO}_{2}$ reductase; A. woodii: Acetobacterium woodii; T. kivui: Thermoanaerobacter kivui; CDW: Cell dry weight; FHL: Formate hydrogen lyase; E. coli: Escherichia coli; ETH2120: N,N,N',N'-Tetracyclohexyl-1,2-phenylenedioxydiacetamide; TCS: 3,3,4,5-Tetrachlorosalicylanilide; DCCD: N,N'-Dicyclohexylcarbodiimide; MES: 2-Morpholin-4-ylethanesulfonic acid; MOPS: 3-Morpholinopropane-1-sulfonic acid; HEPES: 2-[4-(2-Hydroxyethyl)piperazin-1-yl]ethanesulfonic acid; EPPS: 4-(2-Hydroxyethyl)piperazine-1-propanesulfonic acid; CHES: 2-(Cyclohexylamino)ethanesulfonic acid; Tris: 2-Amino-2-(hydroxymethyl)propane-1,3-diol; DTE: Dithioerythritol; $\mathrm{HCO}_{3}{ }^{-}$: Bicarbonate; $t_{\mathrm{D}}$ : Doubling time; $K$ : Equilibrium constant; $\Delta G^{0}$ : Gibbs energy; Mo/W-bis PGD: Molybdenum/tungsten-bis pyranopterin guanosine dinucleotide; CA: Carbonic anhydrase; UVNis: Ultraviolet/visible; OD: Optical density.

\section{Authors' contributions}

VM designed and supervised the research, analyzed the data and wrote the manuscript. FMS designed the research, performed the experiments, analyzed the data and wrote the manuscript. Both authors read and approved the final manuscript

\section{Funding}

This project has received funding from the European Research Council (ERC) under the European Union's Horizon 2020 research and innovation programme (Grant Agreement No 741791).

\section{Availability of data and materials}

All data generated or analyzed during this study are included in this published article.

\section{Ethics approval and consent to participate}

Not applicable.

\section{Consent for publication}

Not applicable.

\section{Competing interests}

The authors declare that they have no competing interests.

Received: 9 November 2019 Accepted: 28 January 2020

Published online: 28 February 2020

\section{References}

1. Munasinghe PC, Khanal SK. Biomass-derived syngas fermentation into biofuels: opportunities and challenges. Bioresour Technol. 2010;101:5013-22.

2. Mondal M, Goswami S, Ghosh A, Oinam G, Tiwari ON, Das P, Gayen K, Mandal MK, Halder GN. Production of biodiesel from microalgae through biological carbon capture: a review. 3 Biotech. 2017;7:99.

3. Bengelsdorf FR, Poehlein A, Linder S, Erz C, Hummel T, Hoffmeister S, Daniel R, Dürre P. Industrial acetogenic biocatalysts: a comparative metabolic and genomic analysis. Front Microbiol. 2016;7:1036.

4. Nevin KP, Hensley SA, Franks AE, Summers ZM, Ou J, Woodard TL, Snoeyenbos-West OL, Lovley DR. Electrosynthesis of organic compounds from carbon dioxide is catalyzed by a diversity of acetogenic microorganisms. Appl Environ Microbiol. 2011;77:2882-6.

5. Müller V. New horizons in acetogenic conversion of one-carbon substrates and biological hydrogen storage. Trends Biotechnol. 2019;37:1344-54.

6. Bengelsdorf FR, Straub M, Dürre P. Bacterial synthesis gas (syngas) fermentation. Environ Technol. 2013;34:1639-51.

7. Daniell J, Köpke M, Simpson SD. Commercial biomass syngas fermentation. Energies. 2012;5:5372-417.

8. Drake HL. Acetogenesis, acetogenic bacteria, and the acetyl-CoA pathway: past and current perspectives. In: Drake HL, editor. Acetogenesis. New York: Chapman and Hall; 1994. p. 3-60.

9. Müller V, Inkamp F, Rauwolf A, Küsel K, Drake HL. Molecular and cellular biology of acetogenic bacteria. In: Nakano M, Zuber P, editors. Strict and facultative anaerobes Medical and environmental aspects. Norfolk: Horizon Scientific Press; 2004. p. 251-81.

10. Wang S, Huang H, Kahnt J, Mueller AP, Köpke M, Thauer RK. NADP-specific electron-bifurcating [FeFe]-hydrogenase in a functional complex with formate dehydrogenase in Clostridium autoethanogenum grown on CO. J Bacteriol. 2013;195:4373-86.

11. Yamamoto I, Saiki T, Liu SM, Ljungdahl LG. Purification and properties of NADP-dependent formate dehydrogenase from Clostridium thermoaceticum, a tungsten-selenium-iron protein. J Biol Chem. 1983;258:1826-32.

12. Maia LB, Moura JJ, Moura I. Molybdenum and tungsten-dependent formate dehydrogenases. J Biol Inorg Chem. 2015;20:287-309.

13. Schwarz FM, Schuchmann $\mathrm{K}$, Müller V. Hydrogenation of $\mathrm{CO}_{2}$ at ambient pressure catalyzed by a highly active thermostable biocatalyst. Biotechnol Biofuels. 2018;11:237.

14. Schuchmann K, Müller V. Direct and reversible hydrogenation of $\mathrm{CO}_{2}$ to formate by a bacterial carbon dioxide reductase. Science. 2013;342:1382-5

15. Kottenhahn P, Schuchmann K, Müller V. Efficient whole cell biocatalyst for formate-based hydrogen production. Biotechnol Biofuels. 2018;11:93.

16. Preuster P, Papp C, Wasserscheid P. Liquid organic hydrogen carriers (LOHCs): toward a hydrogen-free hydrogen economy. Acc Chem Res. 2017;50:74-85.

17. Enthaler S, von Langermann J, Schmidt T. Carbon dioxide and formic acid-the couple for environmental-friendly hydrogen storage? Energy Environ Sci. 2010:3:1207-17.

18. McDowall JS, Murphy BJ, Haumann M, Palmer T, Armstrong FA, Sargent F. Bacterial formate hydrogenlyase complex. Proc Natl Acad Sci USA. 2014;111:E3948-56

19. Pinske C, Sargent F. Exploring the directionality of Escherichia coli formate hydrogenlyase: a membrane-bound enzyme capable of fixing carbon dioxide to organic acid. Microbiologyopen. 2016;5:721-37.

20. Bertsch J, Müller V. CO metabolism in the acetogen Acetobacterium woodii. Appl Environ Microbiol. 2015;81:5949-56.

21. Bertsch J, Müller V. Bioenergetic constraints for conversion of syngas to biofuels in acetogenic bacteria. Biotechnol Biofuels. 2015;8:210.

22. Weghoff MC, Müller V. CO metabolism in the thermophilic acetogen Thermoanaerobacter kivui. Appl Environ Microbiol. 2016;82:2312-9.

23. Schölmerich MC, Müller V. Energy conservation by a hydrogenasedependent chemiosmotic mechanism in an ancient metabolic pathway. Proc Natl Acad Sci USA. 2019;116:6329-34

24. Biegel E, Müller V. Bacterial $\mathrm{Na}^{+}$-translocating ferredoxin:NAD+ oxidoreductase. Proc Natl Acad Sci USA. 2010;107:18138-42.

25. Müller $V$, Aufurth S, Rahlfs S. The $\mathrm{Na}^{+}$cycle in Acetobacterium woodii: identification and characterization of a $\mathrm{Na}^{+}$-translocating $\mathrm{F}_{1} \mathrm{~F}_{\mathrm{O}}$-ATPase with 
a mixed oligomer of 8 and $16 \mathrm{kDa}$ proteolipids. Biochim Biophys Acta. 2001;1505:108-20.

26. Hess V, Poehlein A, Weghoff MC, Daniel R, Müller V. A genome-guided analysis of energy conservation in the thermophilic, cytochrome-free acetogenic bacterium Thermoanaerobacter kivui. BMC Genomics. 2014;15:1139.

27. Yang H, Drake HL. Differential effects of sodium on hydrogen- and glucose-dependent growth of the acetogenic bacterium Acetogenium kivui. Appl Environ Microbiol. 1990;56:81-6.

28. Leigh JA, Mayer F, Wolfe RS. Acetogenium kivui, a new thermophilic hydrogen-oxidizing, acetogenic bacterium. Arch Microbiol. 1981;129:275-80.

29. Roger M, Brown F, Gabrielli W, Sargent F. Efficient hydrogen-dependent carbon dioxide reduction by Escherichia coli. Curr Biol. 2018;28:140-5.

30. Braus-Stromeyer SA, Schnappauf G, Braus GH, Gössner AS, Drake HL. Carbonic anhydrase in Acetobacterium woodii and other acetogenic bacteria. J Bacteriol. 1997;179:7197-200.

31. Das A, Ljungdahl LG. Clostridium pasteurianum $F_{1} F_{0}$ ATP synthase: operon, composition, and some properties. J Bacteriol. 2003;185:5527-35.

32. Lodeyro AF, Calcaterra NB, Roveri OA. Inhibition of steady-state mitochondrial ATP synthesis by bicarbonate, an activating anion of ATP hydrolysis. Biochim Biophys Acta. 2001;1506:236-43.

33. Ebel RE, Lardy HA. Stimulation of rat liver mitochondrial adenosine triphosphatase by anions. J Biol Chem. 1975;250:191-6.

34. Recktenwald E, Hess B. Allosteric influence of anions on mitochondrial ATPase of yeast. FEBS Lett. 1977;76:25-8.

35. Du ZY, Boyer PD. On the mechanism of sulfite activation of chloroplast thylakoid ATPase and the relation of ADP tightly bound at a catalytic site to the binding change mechanism. Biochemistry. 1990;29:402-7.

36. Hartog AF, Edel CM, Braham J, Muijsers AO, Berden JA. FSBA modifies both $\alpha$ - and $\beta$-subunits of $F 1$ specifically and can be bound together with AXP at the same alpha-subunit. Biochim Biophys Acta. 1997:1318:107-22.

37. Alissandratos A, Kim HK, Easton CJ. Formate production through carbon dioxide hydrogenation with recombinant whole cell biocatalysts. Bioresour Technol. 2014;164:7-11.

38. Stephenson M, Stickland LH. Hydrogenlyases: bacterial enzymes liberating molecular hydrogen. Biochem J. 1932;26:712-24.

39. Mourato C, Martins M, da Silva SM, Pereira IAC. A continuous system for biocatalytic hydrogenation of $\mathrm{CO}_{2}$ to formate. Bioresour Technol. 2017;235:149-56.

40. Lin B, Tao Y. Whole-cell biocatalysts by design. Microb Cell Fact. 2017;16:106.

41. Mauerhofer LM, Pappenreiter P, Paulik C, Seifert AH, Bernacchi S, Rittmann SKR. Methods for quantification of growth and productivity in anaerobic microbiology and biotechnology. Folia Microbiol. 2019;64:321-60.

42. Richter K, Nottelmann S. An empiric steady state model of lactate production in continuous fermentation with total cell retention. Eng Life Sci. 2004:4:426-32.

43. Okabe M, Oda A, Park YS, Noguchi K, Okamoto T, Mitsui S. Continuous beer fermentation by high cell-density culture of bottom brewer's yeast. J Ferment Bioeng. 1994;77:41-5.
44. Henstra AM, Sipma J, Rinzema A, Stams AJ. Microbiology of synthesis gas fermentation for biofuel production. Curr Opin Biotechnol. 2007:18:200-6.

45. Liew F, Martin ME, Tappel RC, Heijstra BD, Mihalcea C, Köpke M. Gas fermentation-a flexible platform for commercial scale production of lowcarbon-fuels and chemicals from waste and renewable feedstocks. Front Microbiol. 2016;7:694.

46. Liew F, Henstra AM, Köpke M, Winzer K, Simpson SD, Minton NP. Metabolic engineering of Clostridium autoethanogenum for selective alcohol production. Metab Eng. 2017:40:104-14.

47. Köpke M, Held C, Hujer S, Liesegang H, Wiezer A, Wollherr A, Ehrenreich A, LiebI W, Gottschalk G, Dürre P. Clostridium ljungdahlii represents a microbial production platform based on syngas. Proc Natl Acad Sci USA. 2010;107:13087-92.

48. LubitzW, Ogata H, Rudiger O, Reijerse E. Hydrogenases. Chem Rev. 2014:114:4081-148

49. Goldet G, Brandmayr C, Stripp ST, Happe T, Cavazza C, Fontecilla-Camps $J$ C, Armstrong FA. Electrochemical kinetic investigations of the reactions of [FeFe]-hydrogenases with carbon monoxide and oxygen: comparing the importance of gas tunnels and active-site electronic/redox effects. J Am Chem Soc. 2009;131:14979-89.

50. Baffert C, Bertini L, Lautier T, Greco C, Sybirna K, Ezanno P, Etienne E, Soucaille P, Bertrand P, Bottin $\mathrm{H}$, et al. CO disrupts the reduced $\mathrm{H}$-cluster of FeFe hydrogenase. A combined DFT and protein film voltammetry study. J Am Chem Soc. 2011;133:2096-9.

51. Bryant MP. Commentary on the Hungate technique for culture of anaerobic bacteria. The American journal of clinical nutrition. 1972;25:1324-8.

52. Hungate RE. A roll tube method for cultivation of strict anaerobes. In: Norris JR, Ribbons DW, editors. Methods in microbiology, vol. 3b. New York and London: Academic Press; 1969. p. 117-32.

53. Heise R, Müller V, Gottschalk G. Presence of a sodium-translocating ATPase in membrane vesicles of the homoacetogenic bacterium Acetobacterium woodii. Eur J Biochem. 1992;206:553-7.

54. Schmidt K, Liaaen-Jensen S, Schlegel HG. Die Carotinoide der Thiorhodaceae. Arch Mikrobiol. 1963;46:117-26.

55. Kimmich GA, Randles J, Brand JS. Assay of picomole amounts of ATP, ADP and AMP using the luciferase enzyme system. Anal Biochem. 1975:69:187-206.

56. Lowry OH, Rosebrough NJ, Farr AL, Randall RJ. Protein measurement with the Folin-phenol reagent. J Biol Chem. 1951;193:265-75.

\section{Publisher's Note}

Springer Nature remains neutral with regard to jurisdictional claims in published maps and institutional affiliations.

Ready to submit your research? Choose BMC and benefit from:

- fast, convenient online submission

- thorough peer review by experienced researchers in your field

- rapid publication on acceptance

- support for research data, including large and complex data types

- gold Open Access which fosters wider collaboration and increased citations

- maximum visibility for your research: over 100M website views per year

At BMC, research is always in progress.

Learn more biomedcentral.com/submissions 